\title{
Model system for optimising mRNA non-isotopic in situ hybridisation: Riboprobe detection of lysozyme mRNA in archival gut biopsy specimens
}

\author{
J C Martinez-Montero, C S Herrington, J Stıckland, H Sawyer, M Evans, \\ D M J Flannery, J O’D McGee
}

\begin{abstract}
The aim of this study was to optimise conditions for mRNA detection by nonisotopic in situ hybridisation (NISH) using biotinylated and digoxigenin labelled riboprobes. Because lysozyme gene transcripts are present at high concentrations in Paneth and other alimentary cells, archival gut biopsy specimens were chosen as a model system for these experiments. Most of the variables in NISH, from unmasking of mRNA, to its ultimate detection by peroxidase or alkaline phosphatase based detection systems, were examined in detail. The most important findings were that simultaneous heating of tissue targets and riboprobes at $95^{\circ} \mathrm{C}$ for 15 minutes before hybridisation at $50^{\circ} \mathrm{C}$ for two hours gave the most intense signal for lysozyme mRNA in Paneth cells, Brunner's glands, and lamina propria macrophages; digoxigenin labelled riboprobes gave a higher signal to noise ratio than their biotinylated counterparts, and probes 600 base pairs long were superior to shorter probes. It is concluded that the mRNA NISH method may be generally useful for detecting gene transcription in archival clinical biopsy specimens.
\end{abstract}

Non-isotopic in situ hybridisation (NISH) has been developed for the precise localisation. of nucleic acids in intact cells. In diagnostic molecular pathology most of the effort has been directed towards DNA identification by NISH in archival tissue samples. ${ }^{2}$ For full pathobiological analysis of disease, equally sensitive methodology for mRNA detection in archival biopsy needs to be developed. The most commonly used probes for mRNA detection are radiolabelled riboprobes, the signal being detected by autoradiography. Single radioactive oligonucleotides have also been used but these have theoretical disadvantages $^{3}$ which may be circumvented for some gene transcripts by non-isotopically labelled oligonucleotide cocktails. ${ }^{4}$ The development of reproducible NISH protocols for riboprobe mRNA detection would have several advantages: non-isotopic probes have a longer shelflife; biohazard and disposal are nonproblematic; time-consuming autoradio- graphy is avoided; and labelled riboprobes are easily produced. NISH also provides more precise cellular resolution than autoradiography.

Biotinylated probes have been used extensively to label DNA probes but endogenous biotin produces background noise in some organs. ${ }^{5}$ Since the introduction of digoxigenin labelled probes for $\mathrm{NISH}^{6}{ }^{67}$ the general experience has been that background is less of a problem with this reporter: it is a plant alkaloid and, unlike biotin (vitamin $\mathrm{H}$ ), it is not a physiological tissue constituent and is uncharged at neutral $\mathrm{pH}$. The improved methodology for digoxigenin detection makes this the reporter of choice in most NISH DNA experiments. ${ }^{5}$

Lysozyme mRNA in archival clinical gut biopsy specimens was chosen as a model system to optimise NISH procedures for identification of gene transcription in archival clinical biopsy specimens. This protein ${ }^{8}$ and $\mathrm{mRNA}^{9}$ are present in appreciable quantities in well defined cell populations, such as Paneth cells and lamina propria mononuclear cells. We analysed the following NISH variables for mRNA localisation by digoxigenin and biotin labelled riboprobes: (i) unmasking conditions for mRNA; (ii) prehybridisation requirements; (iii) hybridisation conditions; (iv) optimisation of detection systems; and (v) the efficacy of RNAse inhibitors.

\section{Methods}

All reagents were obtained from Sigma (UK) or BDH (UK) unless otherwise stated. Sixteen routine formalin fixed, paraffin wax embedded endoscopic biopsy specimens of histopathologically normal small or large bowel were obtained from our diagnostic archival file: these included two rectal biopsy specimens of Crohn's colitis. Four small bowel surgical resection specimens were also studied after various fixation times. Sections ( $4 \mu \mathrm{m}$ thick) were mounted on multi-well slides with four wells (12 $\mathrm{mm}$ in diameter) per slide (Henley, Essex) that had been previously coated with aminopropyl-triethoxysilane, and baked at $75^{\circ} \mathrm{C}$ for 60 minutes and overnight at $60^{\circ} \mathrm{C} .{ }^{10}$ Slides were heated at $75^{\circ} \mathrm{C}(10$ minutes $)$ and immediately transferred while still hot, to xylene in which they were gently washed with shaking at $22^{\circ} \mathrm{C}$ twice for 10 minutes each wash to remove the wax. Slides were immersed in
O'D McGee

Professor J O'D McGee

Accepted for publication 22 May 1991 
methanol for 10 minutes, twice, and quickly rinsed (three times) in double distilled water $\left(\mathrm{ddH}_{2} \mathrm{O}\right)$. Sections were warmed in $\mathrm{ddH}_{2} \mathrm{O}$ at $37^{\circ} \mathrm{C}$ while the proteases were prepared (see below).

\section{RIBOPROBES}

The lysozyme probe was a 642 base pair human lysozyme cDNA, subcloned in both orientations into the Hinc II site of pGEM-3 (Promega Biotec, Madison, Wisconsin, USA). The recombinant plasmids were purified, linearised with Hind III, and transcribed with T7 RNA polymerase to generate anti-sense RNA probes. For sense RNA probes, the plasmids were linearised with $E c o R I$ and transcribed with SP6 polymerase. An unrelated control probe, the 800 base pair fragment of the $3^{\prime}$ end of a p53 cDNA, was subcloned into the SmaI/BamHI sites of pBluescribe (Stickland J, Evans M, McGee J O'D, unpublished observations). EcoRI and Hind $I I I$ linearised plasmids were used to synthesise both sense and antisense riboprobes with T3 and T7 RNA polymerases, respectively.

Riboprobes were labelled with digoxigenin11-UTP (Boehringer, Germany) or biotin-11UTP at concentrations of $350 \mu \mathrm{M} / 1$ and $1.375 \mathrm{mM} / 1$, respectively, in the transcription reaction using a protocol based on that of Höltke and Kessler. ${ }^{11}$ The labelled probes were digested with DNAse and extracted with phenol/chloroform and chloroform. Probe size and qualitative assessment of label incorporation was by gel electrophoresis of glyoxal denatured probe, followed by transfer to nitrocellulose filters, and biotin probes were detected as described ${ }^{12}$ : for digoxigenin detection, anti-digoxigenin antibody was used. Full length probes (median length 600 base pairs) were hydrolysed with alkali to an average size of 150 nucleotides (100-200 base pairs), as estimated by non-isotopic Northern blotting. ${ }^{12}$

\section{NON-ISOTOPIC IN SITU HYBRIDISATION \\ Proteolysis}

Nucleic acids were "unmasked" by exposing sections to pepsin $/ \mathrm{HCl}$ or proteinase $\mathrm{K}$ for 20 and 15 minutes respectively at $37^{\circ} \mathrm{C}$. Pepsin/ $\mathrm{HCl}$ (specific activity $=3.200 \mathrm{IU} / \mathrm{mg}$ protein) was prepared as described previously. ${ }^{10}$ Proteinase $\mathrm{K}$ was dissolved to a concentration of $500 \mu \mathrm{g} / \mathrm{ml}$ (specific activity $=20 \mathrm{IU} / \mathrm{mg}$ protein, Boehringer Mannheim, UK), in phosphate buffered saline (PBS) $\left(10 \mathrm{mM} \mathrm{Na} \mathrm{HPO}_{4}\right.$, $1.5 \mathrm{mM} \mathrm{KH}, 150 \mathrm{mM} \mathrm{NaCl}, \mathrm{pH} \mathrm{7.4)}$. After proteolysis sections were quickly rinsed in PBS, ddH $\mathrm{H}_{2} \mathrm{O}$, and post-fixed in $2 \%$ paraformaldehyde $(w / v)$ in PBS for five minutes, followed by quick rinses in $\mathrm{PBS}, \mathrm{ddH}_{2} \mathrm{O}$, methanol, and dried at $37^{\circ} \mathrm{C}$.

\section{Prehybridisation/hybridisation}

To assess the effect of prehybridisation sections were covered with $140 \mu \mathrm{l}$ of hybridisation mix without probe; PBS alone was used as a control. Sections were incubated in moist Terasaki plates for 30 minutes at $37^{\circ} \mathrm{C}$. Slides were drained and $8 \mu \mathrm{l}$ of hybridisation mix containing digoxigenin labelled $(0.4 \mathrm{ng} / \mu \mathrm{l})$, or biotinylated antisense riboprobe $(0.06 \mathrm{ng} / \mu \mathrm{l})$, was pipetted on to each well and individual wells covered with a circular glass coverslip (14 mm in diameter); these were not sealed. Hybridisation mix contained $50 \%(\mathrm{v} / \mathrm{v})$ formamide, $5 \%$ (v/v) dextran sulphate, $2 \times \mathrm{SSC}, 0.1 \mathrm{mM}$ EDTA, $1 \mathrm{mM}$ TRIS-HCl (pH 7.3), and Escherichia coli tRNA to a final concentration of $100 \mathrm{mg} / \mathrm{ml} ; 1 \times \mathrm{SSC}=0.15 \mathrm{M}$ sodium chloride, $0.015 \mathrm{M}$ sodium citrate. All solutions used in the hybridisation mix were prepared using $\mathrm{ddH}_{2} \mathrm{O}$ that had been previously treated with $0.1 \% \quad(\mathrm{v} / \mathrm{v})$ diethyl pyrocarbonate (DEPC).

The multi-well slides in moist Terasaki plates were subsequently treated as follows. One set was heated at $95^{\circ} \mathrm{C}$ in a hot air oven for 15 minutes and hybridised at $42^{\circ} \mathrm{C}$ or $50^{\circ} \mathrm{C}$ for two, four, six, or 16 hours. The second set were hybridised (without preheating at $95^{\circ} \mathrm{C}$ ) at $42^{\circ} \mathrm{C}$ or $50^{\circ} \mathrm{C}$ for the same times. Each set was also hybridised with hydrolysed and nonhydrolysed riboprobes under both sets of conditions.

Negative controls consisted of sections on the same multi-well slide incubated with the same quantity of labelled lysozyme sense probe, or with hybridisation mix only; unrelated digoxigenin labelled p53 sense and anti-sense riboprobes were also hybridised to consecutive sections. Competitive studies were carried out by incubating sections with hybridisation mix containing both labelled anti-sense and sense lysozyme riboprobes.

\section{Post-hybridisation treatment}

Coverslips were removed by washing for 10 minutes in $2 \times \mathrm{SSC}$ at $22^{\circ} \mathrm{C}$ (twice, for six minutes each) and sections incubated with $150 \mu \mathrm{g} / \mathrm{ml} \mathrm{RNAse} \mathrm{A} \mathrm{(Sigma} \mathrm{UK)} \mathrm{in} 2 \times$ SSC for 30 minutes at $37^{\circ} \mathrm{C}(140 \mu \mathrm{l}$ per well $)$. To investigate the effect of post-hybridisation washes on background noise, slides were washed at higher stringency in $0.2 \times \mathrm{SSC} /$ $50 \%$ formamide at $50^{\circ} \mathrm{C}$ for 30 minutes. Slides were then washed in TBT blocking solution (0.05 M TRIS/ $\mathrm{HCl}, 0.1$ sodium chloride, $\mathrm{pH}$ 7.5 , containing $0.25 \%(\mathrm{w} / \mathrm{v})$ bovine serum albumin and $0.05 \%$ Triton X100 (v/v) at $22^{\circ} \mathrm{C}$ for 10 minutes.

\section{DETECTION OF NISH SIGNAL}

Biotinylated probes

Slides were incubated in a moist chamber at $22^{\circ} \mathrm{C}$ for 30 minutes with mouse monoclonal anti-biotin antibody (Dako UK) diluted 1 in 50 in TBT; biotinylated $\left(\mathrm{Fab}^{\prime}\right)_{2}$ rabbit anti-mouse immunoglobulins (Dako UK) diluted 1 in 200 for 30 minutes; washed in TBS (50 mM TRIS/ $\mathrm{HCl}, \mathrm{pH} 7 \cdot 2,100 \mathrm{mM} \mathrm{NaCl}, 1 \mathrm{mM} \mathrm{MgCl}_{2}$ ), and incubated for 30 minutes with alkaline phosphatase or peroxidase conjugated streptavidin (Dako UK) diluted 1 in 50 or 1 in 75 , respectively, in TBT containing $5 \%$ nonfat dried milk (Cadbury UK). After two five minute washes in TBS alkaline phosphatase was detected by incubation in nitroblue tetrazolium containing 5-bromo-4-chloro- 3indolyl-phosphate (NBT/BCIP) substrate ${ }^{10}$ in the dark-that is, in a drawer or regular cupboard, for one to 16 hours at $22^{\circ} \mathrm{C}$. Peroxidase was detected by incubating in 3-amino-9ethylcarbazole (AEC), hydrogen peroxide. ${ }^{5}$ 

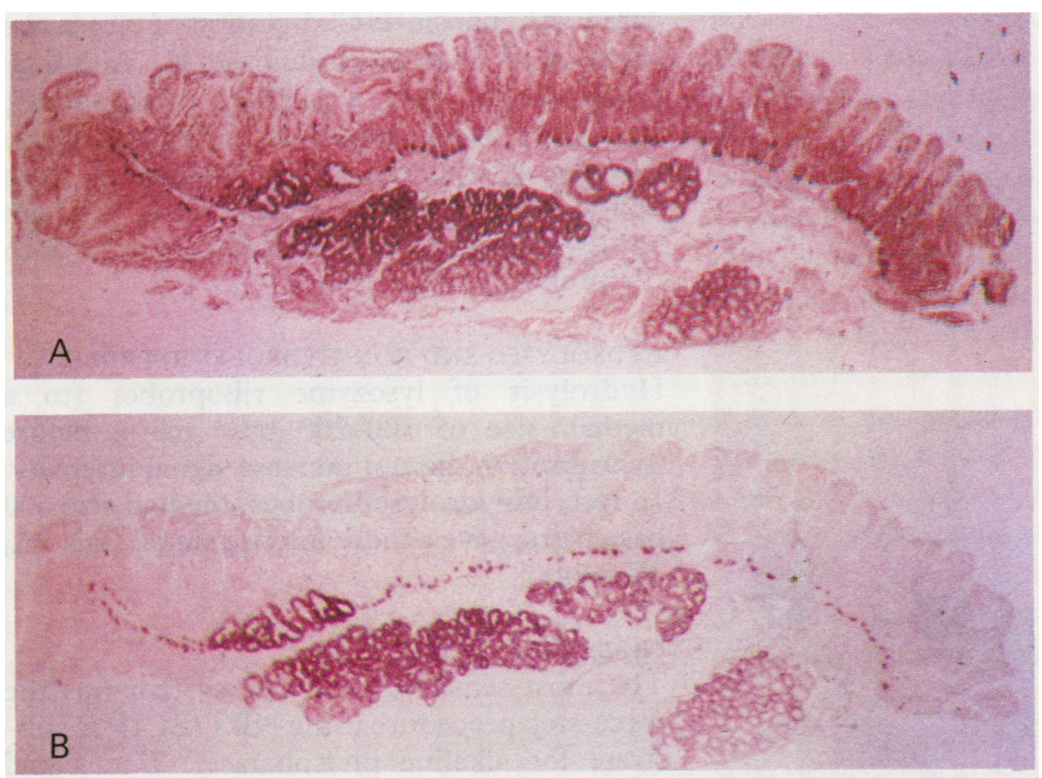

Figure 1 Lysozyme mRNA in Paneth cells and Brunner's glands in an archival small bowel biopsy specimen. This section was hybridised with $(A)$ biotin and $(B)$ digoxigenin labelled lysozyme anti-sense riboprobe using optimal conditions for $m R N A$ detection. Background is higher with the biotinylated probe.

\section{Digoxigenin labelled probes}

Two systems were compared: (1) slides were incubated for 30 minutes with alkaline phosphatase conjugated anti-digoxigenin polyclonal antibody (Boehringer, Germany), diluted 1 in 500-1 in 5000 in TBT. The signal was detected as described. ${ }^{6}$ (2) A three-step amplification system was also used. ${ }^{5}$ Briefly, slides were incubated for 30 minutes with monoclonal anti-digoxigenin antibody (Sigma UK), diluted 1 in 10000 in TBT, washed in TBS, and incubated with biotinylated $\left(\mathrm{Fab}^{\prime}\right)_{2}$ fragment of rabbit antimouse immunoglobulins (Dako UK) diluted 1 in 200 for 30 minutes. Slides were washed in TBS, incubated for 30 minutes in alkaline phosphatase or peroxidase conjugated-streptavidin (Dako UK) diluted 1 in 50 and 1 in 75, respectively, in TBT containing 5\% non-fat milk, washed in TBT (twice for five minutes each), and incubated in NBT/BCIP in the dark for one to 16 hours or in $\mathrm{AEC} / \mathrm{H}_{2} \mathrm{O}_{2}$ (see above). Fast red was also tested as substrate for alkaline phosphatase. ${ }^{5}$ Reactions were stopped in distilled water and slides dried at $37^{\circ} \mathrm{C}$, counter- stained with methyl green or haematoxylin and eosin, and mounted in glycerol jelly.

To determine whether the NISH signal was due to DNA or RNA, sections were digested with DNAse or RNAse after proteolysis but before paraformaldehyde post-fixation and hybridisation. RNAse A was dissolved in dd$\mathrm{H}_{2} \mathrm{O}$ at $10 \mathrm{mg} / \mathrm{ml}$, boiled for 10 minutes, and diluted to $100 \mu \mathrm{g} / \mathrm{ml}$ in $2 \times$ SSC. DNAse 1 free of RNAse (Boehringer, Germany) was dissolved at $200 \mu \mathrm{g} / \mathrm{ml}$ in $0.01 \mathrm{M}$ TRIS $/ \mathrm{HCl}$ ( $\mathrm{pH}$ 7.5), containing $0.01 \mathrm{M}$ magnesium chloride. RNAse or DNAse solutions $(140 \mu \mathrm{l})$ were placed over each well and incubated for 30 minutes at $37^{\circ} \mathrm{C}$; as controls sections were incubated in the same buffers without enzyme. Sections were then washed in $2 \times$ SSC, rinsed in $\mathrm{ddH}_{2} \mathrm{O}$, post-fixed in $2 \%$ paraformaldehyde $(\mathrm{v} / \mathrm{v})$ in PBS for five minutes and hybridised with or without labelled sense or anti-sense lysozyme riboprobes.

\section{Results}

The most widely used protocols for mRNA detection with riboprobes require hybridisation at $42^{\circ} \mathrm{C}-50^{\circ} \mathrm{C}$ for 12 to 16 hours. ${ }^{13}$ This is usually preceded by prehybridisation treatment of slides and followed by post-hybridisation digestion with RNAse. We used this protocol as the "comparator system" against which we judged the effect of modifying the variables tested (see below). The protocol which has been evolved detected lysozyme mRNA in Paneth cells, Brunner's glands, and in some cases, mononuclear cells in the lamina propria (fig 1, fig 3A).

\section{HYBRIDISATION TEMPERATURE}

The intensity of the signal increased slightly when the hybridisation temperature was increased from $42^{\circ} \mathrm{C}$ to $50^{\circ} \mathrm{C}$ (fig $2 \mathrm{~A}$ ). The use of higher temperatures $\left(55^{\circ} \mathrm{C}, 60^{\circ} \mathrm{C}\right.$, and $\left.65^{\circ} \mathrm{C}\right)$ did not increase signal intensity over that at $50^{\circ} \mathrm{C}$ (table). Drying of the sections was a problem using unsealed slides above $55^{\circ} \mathrm{C}$.

\section{PREHEATING TARGET AND PROBE}

When tissue target and probe were heated for 15 minutes at $95^{\circ} \mathrm{C}$ simultaneously on the slide before hybridising, the signal intensity was
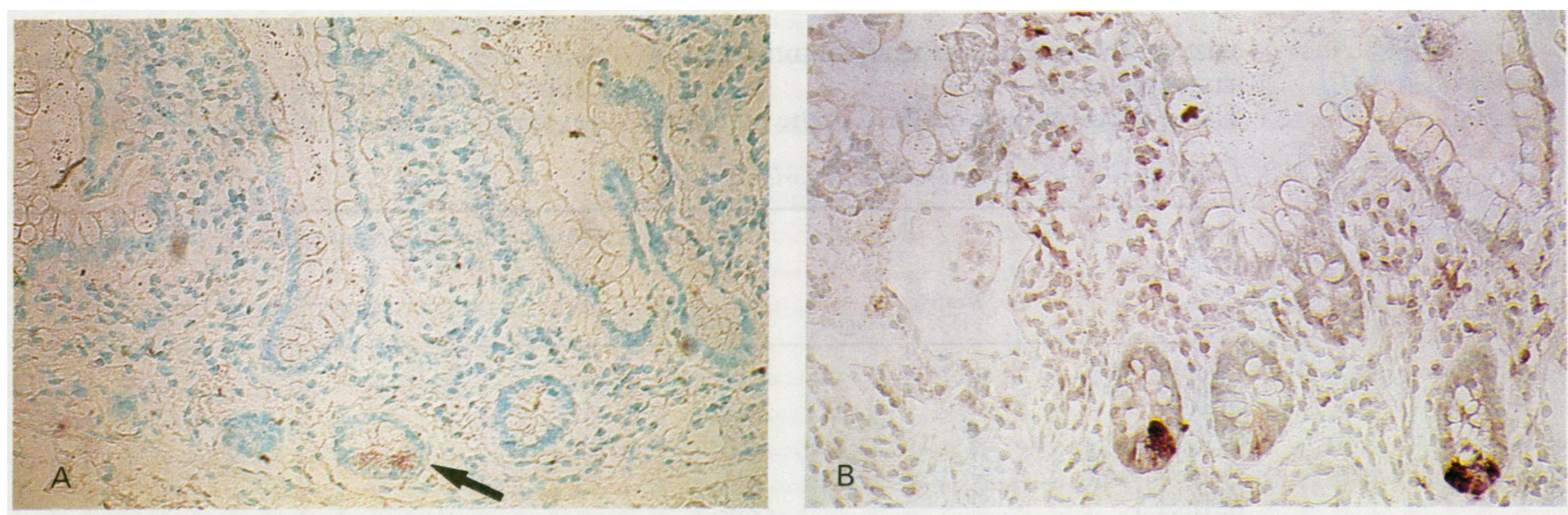

Figure 2 (A) Small bowel biopsy specimens hybridised for two hours at $50^{\circ} \mathrm{C}$, without a preheating step, with digoxigenin labelled lysozyme antisense riboprobe. Paneth cells are just visible (arrow) using the three-step alkaline phosphatase procedure. $(B)$ Small bowel biopsy specimens, heated at $95^{\circ} \mathrm{C}$ for 15 minutes with digoxigenin labelled lysozyme anti-sense riboprobe, and hybridised for two hours at $50^{\circ} \mathrm{C}$. Paneth cells are intensely labelled and lamina propria macrophages are visible. 


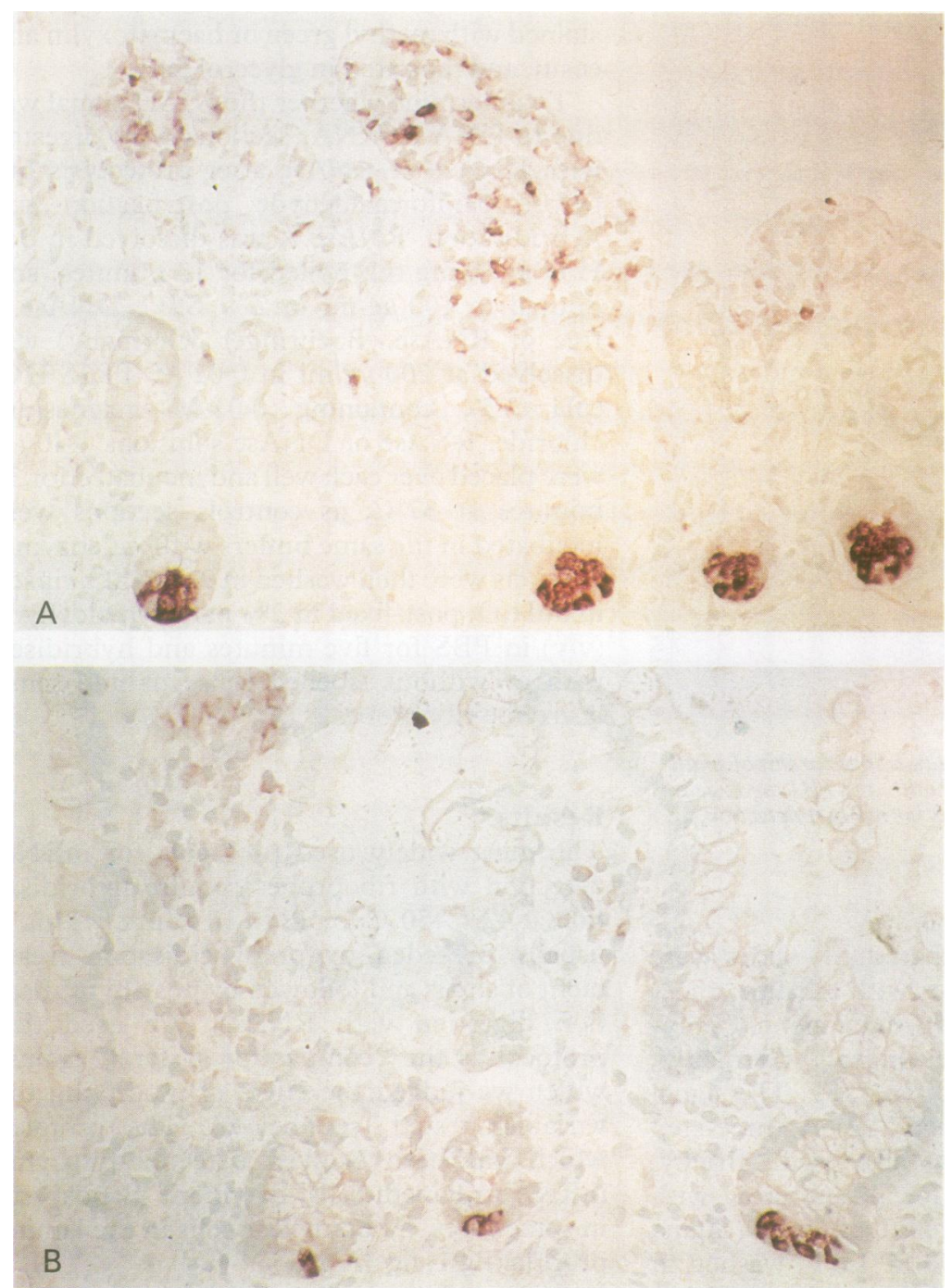

Figure 3 Consecutive sections of a small bowel biopsy specimen hybridised with a prehating step (see fig $2 B$ ) with ( $A$ ) unhydrolysed (600 bases) and (B) hydrolysed (100 to 200 bases) digoxigenin labelled lysozyme anti-sense riboprobe. The intensity of the signal in $(A)$ is higher than $(B)$.

greatly increased and the number of cells in which lysozyme mRNA was detected also increased. With this initial heating step the optimum signal was achieved by hybridising subsequently at $50^{\circ} \mathrm{C}$ for two hours (fig $2 \mathrm{~B}$ ); prolonged hybridisation did not significantly increase the signal (table). In practice, therefore, we heat at $95^{\circ} \mathrm{C}$ for 15 minutes and hybridise at $50^{\circ} \mathrm{C}$ for two hours.

ENZYME DIGESTION AND PREHYBRIDISATION OI TISSUE SECTIONS

Using the conditions outlined in the preceding

Lysozyme mRNA signal as a function of variables tested paragraph, pepsin- $\mathrm{HCl}$ digestion of target was superior to that of proteinase $\mathrm{K}$. Although proteinase $K$ gave a slightly more intense signal, the background was higher and tissue morphology poorer. Prehybridisation with hybridisation mix without probe did not improve the signal to noise ratio obtained with riboprobes in these tissues.

\section{HYDROLYSED AND NON-HYDROLYSED PROBES}

Hydrolysis of lysozyme riboprobes (to a median size of 100-200 base pairs) before hybridisation did not increase signal intensity. In fact, unhydrolysed probes, median size 600 base pairs, gave a more intense signal (figs $3 \mathrm{~A}$, 3B, table).

\section{PROBE DETECTION}

The most sensitive detection system was the three-step procedure using NBT/BCIP as substrate for alkaline phosphatase. ${ }^{5}$ The signal appeared at almost the same time in Brunner's glands and Paneth cells, and was optimal in about 20-30 minutes. To obtain a signal in lamina propria macrophages it was necessary to incubate in substrate for 45 to 60 minutes. While the signal obtained with digoxigenin probes stood out very clearly from a clean background, biotinylated probes produced higher background with these substrate incubation times. With biotinylated probes the background level was high after 45 minutes' incubation in substrate and unacceptable after incubations longer than one hour. NBT/BCIP gave a much more intense signal than Fast red; it was also superior to peroxidase detection of probes by $\mathrm{AEC} / \mathrm{H}_{2} \mathrm{O}_{2}$.

\section{RNASE INHIBITORS}

The use of general measures to protect against free RNAses (gloves, washes with DEPC treated water, and glassware treated with RNAse inhibitors) did not improve the intensity of the signal obtained without using gloves, washing the slides with ultrapure water only, and using only clean glassware. All of our reagents, however, were made up in DEPC treated water.

To examine the effects of fixation on mRNA retention four small bowel biopsy specimens were routinely fixed for two to 48 hours in $10 \%$ buffered formalin and paraffin wax embedded. Sections were hybridised under optimal conditions with digoxigenin labelled riboprobes (table). The intensity of signal in all cell types was similar, irrespective of fixation time.

\section{Lysozyme mRNA signal as a function of variables tested}

\begin{tabular}{|c|c|c|c|c|c|c|}
\hline \multirow[b]{3}{*}{ Probe $^{\star}$} & \multirow{3}{*}{$\begin{array}{l}\text { Heating } \\
\left(95^{\circ} \mathrm{C} / 15 \text { minutes }\right)\end{array}$} & \multirow[b]{3}{*}{ Temperature } & \multicolumn{4}{|c|}{ Hybridisation conditions/signal intensity $\dagger$} \\
\hline & & & \multicolumn{4}{|c|}{ Time (hours) } \\
\hline & & & 2 & 4 & 6 & 16 \\
\hline $\begin{array}{l}\text { Non-hydrolysed } \\
\text { Non-hydrolysed } \\
\text { Hydrolysed } \\
\text { Hydrolysed } \\
\text { Non-hydrolysed } \\
\text { Non-hydrolysed } \\
\text { Hydrolysed } \\
\text { Hydrolysed }\end{array}$ & $\begin{array}{l}0 \\
0 \\
0 \\
0 \\
+ \\
+ \\
+ \\
+\end{array}$ & $\begin{array}{l}42^{\circ} \mathrm{C} \\
50^{\circ} \mathrm{C} \\
42^{\circ} \mathrm{C} \\
50^{\circ} \mathrm{C} \\
42^{\circ} \mathrm{C} \\
50^{\circ} \mathrm{C} \\
42^{\circ} \mathrm{C} \\
50^{\circ} \mathrm{C}\end{array}$ & $\begin{array}{l} \pm 1+ \\
\pm 1+ \\
\pm \\
\pm \\
++++ \\
++++ \\
+++ \\
+++\end{array}$ & $\begin{array}{l} \pm 1+ \\
\pm 1+ \\
\frac{ \pm}{ \pm} \\
+++ \\
+++++ \\
+ \\
+++\end{array}$ & $\begin{array}{l} \pm 1+ \\
t \\
\pm \\
\pm \\
++++ \\
++++t \\
++ \\
++\end{array}$ & $\begin{array}{l}+++ \\
++++ \\
+++ \\
++++ \\
+++++ \\
+++++ \\
++++ \\
+++++\end{array}$ \\
\hline
\end{tabular}

*All probes were digoxigenin labelled.

† Signal intensity was scored independently as $1+$ to $5+$ by two observers; \pm indicates that a signal was just visible. 
CONTROLS

All of the controls with labelled sense probes and hybridisation mix only were negative. The p53 anti-sense probe did not react with Paneth cells or any of the other cell types that reacted with the lysozyme riboprobe. Sections hybridised with both labelled lysozyme antisense and sense probes showed a reduction in signal intensity in this competitive reaction. The incubation with RNAse $A$ before hybridisation abolished the signal. Digestion with DNAse before hybridisation either did not affect or increase signal intensity. RNAse digestion after hybridisation was effective in reducing background but did not affect the specific signal in Paneth cells, etc.

\section{Discussion}

We investigated the transcription of the lysozyme gene and its product in routinely processed tissue sections of human bowel. The heating step at $95^{\circ} \mathrm{C}$ for 15 minutes is the most relevant innovation to improve the sensitivity of NISH on archival tissue sections. Heating before hybridisation produces a strong signal without background after short hybridisations (two hours), which is not attainable without heating. Results, therefore, can be obtained in one day. The heating step probably removes secondary structure from the mRNA, and perhaps riboprobe.

The model used here shows the advantages of digoxigenin as a reporter molecule. The pattern and intensity of the signal obtained with riboprobes labelled with biotin or digoxigenin was the same, but biotinylated probes gave a much higher background that was not abolished even with post-hybridisation RNAse treatment. This was particularly so with long enzyme substrate incubations. A higher signal to noise ratio, therefore, was obtained with digoxigenin labelled probes, particularly with the three-step detection system. Prehybridisation treatments and high stringency post-hybridisation washing did not reduce non-specific background, irrespective of the reporter molecule, suggesting that background is not due to specific hybridisation of probe to tissue components.

Most of the protocols for mRNA detection with riboprobes use hydrolysed probes of 150 200 base pairs, the reasoning being that short fragments penetrate more easily into cells. ${ }^{10}$ In our experiments, however, hydrolysis of RNA probes 600 to $100-200$ base pairs did not give a signal as intense as non-hydrolysed probes. This would argue that probe size is not the only element involved in the production of the final signal.

The identification of lysozyme protein has been used as a marker of macrophages in a variety of organs. $^{8}$ In our experiments lysozyme mRNA in lamina propria cells in normal bowel was almost undetectable. A positive signal for lysozyme mRNA in lamina propria cells, however, was obtained in the rectal biopsy specimens of Crohn's disease. Taken together, these observations suggest that lysozyme transcription and translation are upregulated in those macrophages present in inflammatory disease.
Other protocols for mRNA detection by in situ hybridisation emphasise that, as RNAses are ubiquitous, special measures are necessary, such as gloves, washes with DEPC treated $\mathrm{H}_{2} \mathrm{O}$, and treatment of glassware with RNAse inhibitors, to avoid degradation of mRNA. In our experiments all the reagents were made up with DEPC treated water. Incorporating the other measures was found to be unnecessary. Formalin fixation of tissue may protect the mRNA molecules by cross-linking them to tissue proteins.

In conclusion, this methodology gave consistent results in 16 endoscopic small bowel and two rectal biopsy specimens as well as four small bowel surgical samples that were morphologically normal or chronically inflamed. Heating at $95^{\circ} \mathrm{C}$ for 15 minutes before hybridisation allows hybridisation time to be reduced to two hours, compared with the standard overnight incubation procedures using riboprobes. ${ }^{14}$ Thus the technique can be easily completed in one working day and may be applicable for use in routine laboratories.

This work was supported by grants to JO'DMG from the Cancer Research Campaign CRC (UK); JCMM was supported by a grant from the Fondo de Investigaciones Sanitarias de la Seguridad Social (FISS), Ministerio de Sanidad y Consumo (Spain); and CSH was a CRC Clinical Research Fellow. We (Spain); and CSH was a CRC Clinical Research Fell
thank Professor S Gordon for the lysozyme probe.

1 Herrington CS, Flannery DMJ, McGee JO'D. Single and simultaneous nucleic acid detection in archival human biopsies: application of non-isotopic in situ hybridization and the polymerase chanin reaction to the analysis of human and viral genes. In: Polak JM McGee JO'D eds. In situ hybridization. Principles and practice. Oxford: In situ hybridization. Principles and prac

2 Herrington CS, McGee JO'D. Interphase cytogenetics. Neurochem Res 1990;15:467-74.

3 Lathe R. Oligonucleotide probes for in situ hybridisation. In: Polak JM, McGee JO'D, eds. In situ hybridization: Principles and practice. Oxford: Oxford University Press, 1990:71-80.

4 Akhtar N, Ruprai A, Pringle JH, Lauder I, Durrant STS. In situ hybridization detection of light chain mRNA in routine bone marrow trephines from patients with suspected myeloma. Br J Haematol 1989;73:296-301.

5 Herrington CS, Graham AK, McGee JO'D. Interphase cytogenetics III: Increased sensitivity and flexibility of digoxigenin labelled DNA probes for HPV detection in digoxigenin labelled DNA probes for HPV detection in 1991;44:33-8.

6 Herrington CS, Burns J, Graham AK, Evans M, McGee JO'D. Interphase cytogenetics using biotin and digoxigenin labelled probes I: relative sensitivity of both reporter molecules for detection of HPV 16 in CaSki cells. JClin Pathol 1989;42:592-600.

7 Herrington CS, Burns J, Graham AK, Bhatt B, McGee JO'D. Interphase cytogenetics using biotin and digoxigenin labelled probes II: simultaneous detection of viral and mammalian nucleic acids in individual nuclei. $J$ Clin Pathol 1989;42:601-6.

8 Mason DY, Taylor CR. The distribution of muramidase (lysozyme) in human tissues. J Clin Pathol 1975;28: (124-32.

9 Chung LP, Keshav S, Gordon S. Cloning the human lysozyme cDNA: Inverted Alu repeat in the mRNA and in situ hybridization for macrophages and Paneth cells. Proc Natl Acad Sci (USA) 1988;85:6227-31.

10 Burns J, Graham AK, Frank C, Fleming KA, Evans MF, McGee JO'D. Detection of low copy human papilloma virus DNA and mRNA in routine paraffin wax sections of cervix by non-isotopic in situ hybridisation. J Clin Pathol 1987;40:858-64.

11 Höltke HJ, Kessler C. Non-radioactive labelling of RNA transcripts in vitro with the hapten digoxigenin (DIG); hybridization and ELISA-based detection. Nucleic Acids Res 1990;18:5843-51.

12 Chan VT-W, Fleming KA, McGee JO'D. Detection of subpicogram quantities of specific DNA sequences on blot subpicogram quantities of specific DNA sequences on blot 1985;13:8083-91.

13 Angerer LM, Cox KH, Angerer RC. Demonstration of tissue-specific gene expression by in situ hybridization. In: Berger SL, Kimmel AR, eds. Methods in enzymology Guide to molecular cloning techniques. Vol 152. New York: Academic Press Inc,1987:649-61

14 Hofler H. Principles of in situ hybridization. In: Polak JM McGee JO'D, eds. In situ hybridization: Principles and practice. Oxford: Oxford University Press, 1990:15-29. 